Ministerstwo Nauki

i Szkolnictwa Wyższego

Digitalizacja archiwalnych numerów czasopisma naukowego Analecta Cracoviensia 1-24 (1969-1992)

i ich publikacja w otwartym dostępie - zadanie finansowane w ramach umowy 672/P-DUN/2017 ze środków

Ministra Nauki i Szkolnictwa Wyższego przeznaczonych na działalność upowszechniającą naukę

KS. KAZIMIERZ KEOSAK

\title{
DUSZA LUDZKA W PERSPEKTYWACH FILOZOFII PRZYRODY I METAFIZYKI
}

Zanim przejdę do osnowy metafizycznej definicji duszy ludzkiej, jaką wysuwa się w nurcie perypatetyczno-tomistycznym, by uczynić ostatecznie zrozumiała $w$ aspekcie bytowości poznaną empirycznie organizację każdego $\mathrm{z}$ nas, wskażę najpierw na treść, którą dla rzeczonej duszy - głównie w zakresie jej cech względnych - przyjmuje się przy pierwszych, zaczątkowych próbach filozoficznego samozrozumienia $\mathrm{w}$ definicji z dziedziny fil o z ofii przyrody. Tak postąpię dlatego, gdyż sformułowania metafizyka, dotyczące w przeważającej części cech bezwzględinych duszy ludzkiej, stanowią tylko wyższego rodzaju dopełnienie ckreśleń $\mathrm{w}$ jej przedmiocie, do jakich dochodzi się $\mathrm{w}$ obrębie filozofii przyrody.

\section{DUSZA LUDZKA W UJECIU FILOZOFII PRZYRODY}

1. Ze stanowiska tomistycznej filozofii przyrody dusza jest w człowieku - jak w każdym jestestwie organicznym - pierwszą za$\mathrm{s}$ a dą $\dot{\mathrm{z} y \mathrm{c} i \mathrm{a}}$ (primum principium vitae) ${ }^{1}$, tzn. tym, od czego ostatecznie, chociaż nie bezpośrednio ${ }^{2}$, wywodzą się genetycznie wszystkie ludzkie przejawy witalne ${ }^{3}$. W tym potraktowaniu najbardziej ramo-

1 Tomasz z Akwinu, Sum theol., I, qu. LXXV, a. 1. Zob. jeszcze ibid. a. 2, qu. LXXVI. a. 1, oraz In Aristotelis librum De anima commentarium, ed. Angelus M. Pirotta, Taurini 1925, lib. II, lect. I, n. 220, s. 81, n. 230, s. 83, lect II, n. 240 , s. 87 , lect. III, n. 253 , s. 91 , n. 261 , s. 93 , lect. IV, n. 273 , s. 97 , i quaest. disp. De anima, a. 1.

W tych tekstach, które dotyczą nie tylko duszy ludzkiej, myśl, że ta dusza czy inna (wegetatywna i zmysłowa) jest pierwszą zasadą życia, została wyrażona niejednokrotnie w sposób domyślny. Chodzi tu o wypowiedzi tego typu: ,per animam [...] intelligimus id, quo habens vitam vivit; anima est primum quo et vivimus, et sentimus, et movemur, et intelligimus"

Zob. Tomasza: Sum. c. Gent., lib. II, cap. LXXI; Quodlibetum X, qu. III, a. 5; quaest. disp. De anima, a. 12; Sum theol., I, qu. LXXVII, a. 1.

3 Zasade Tomasz pojmowal jako wszystko to, od czego zaczyna sie ruch - ,omne id a quo incipit motus" (De principiis naturae, w: Opuscula 
wym, najmniej sprecyzowanym, dusza ludzka przedstawia się jako coś z konkretnego bytu człowieka ${ }^{4}$, jako jakaś jego c z ę ś ć.

Określając $w$ ten sposób $w$ pierwszym, wstępnym rzucie pozycję egzystencjalną duszy ludzkiej, bierze się ją $w$ jej bycie zasadnic zym - a więc w tym, co w niej występuje w aspekcie statycznym i dynamicznym jako ostateczny podmiot w ścisłym rozumieniu, jako to, czego $z$ niej nie można orzekać o kimś drugim. Ponadto, wcale nie chce się powiedzieć, że nasza dusza rozpatrywana pod względem swojej szczególnej „osi” czy „trzonu” swej budowy — jak moglibyśmy się wyrazić zmieniając zastosowanie obrazowego określenia, użytego przez Romana Ingardena ${ }^{5}$ - stanowi w stosunku do wszystkich swoich przejawów życiowych ich pełny i wyłąc c ny podmiot ostateczny. Wiele bowiem spośród nich - chodzi o przejawy życia wegetatywnego i zmysłowego - znajduje ostateczne zapodmiotowanie w całym ludzkim compositum ${ }^{6}$, chociaż i one wywodzą się pierwiastkowo z duszy jako swej pierwszej zasady ${ }^{7}$.

2. Według przedstawionego ujęcia jest dusza ludzka w zakresie swego bytu zasadniczego pierwszym ,aktem", czyli pierw'szą doskonałością bytową naszego ciała organicznego, stanowiącą bezpośredni czynnik całej jego aktualizacji, gdyż ono przez nią istnieje jako ciało oraz jako ciało organiczne, i jako ciało mające życie w mo-

omnia, cura et situdio Petri Mandionnet, Parisiis 1927, t. I, 12), lub ogólniej jako wszystko, od czego coś pochodzi (bierze początek) w jakikolwiek spośnb_ ,omne [...] a quo aliquid procedit quocumque modo" (Sum. theol., I, qu. XXXIII, a. 1). Stosując do duszy ludzkiej definicję zasady $\mathrm{w}$ pierwszym sformułowaniu, bierze się ruch w szerokim rozumieniu, ,prout etiam intellectualis operatio motus quidam dicitur" (komentarz Tomasza do De anima, lib. II, lect. I, n. 219, s. 81).

4 Jako ,aliquid in subiecto existens", jak wyraził się Tomasz w komentarzu do De anima, lib. II, lect I, n. 220, dodając zaraz, że $\mathrm{w}$ tym wypadku ma na uwadze podmiot szeroko rozumiany, ,non sollum prout subiectum dicitur aliquid ens actu, per quem modum accidens dicitur esse in subiecto; sed etiam secundum quod materia prima, quae est ens in potentia, dicitur subiectum". Talkie szerokie rozumienie podmiotu narzuca się, zdaniem Tomasza, z tej racji, że ,corpus [...], quold recipit vitam, magis est sicut subiectum et materia quam sicut aliquid in subiecto existens" (tamże).

5 Spór o istnienie świata, t. II, Warszawa $1961^{2}$, 520. Dla Ingardena „osią" czy ,trzonem” budowy duszy ludzkiej jest „czysty podmiot strumienia świadomości".

6 Zoib. Tomasza: Sum. c. Gent., lib. II, cap. LVII, LXVIII; komentarz do De anima, lib. II, lect IV n. 271, s. 97; quaest. disp. De anima, a 19; Sum theol., I, qu. LXXV, a. 3-4, qu. LXXVII, a. 8, qu. LXXXVIII, a. 1, qu. LXXXIV, a. 6.

7 Oto, co Tomasz pisał o przejawach życia zmysłowego i o ich władzach: „Nulla operatio partis sensitivae potest esse animae tantum ut operetur; sed est compositi per a n imam [...]. Compositum igitur est videns et audiens, et omnia sentiens, sed per animam; unde etiam compositum est potens videre et audire et sentire, sed per an imam. Manifestum est ergo quod potentiare partis sensitivae sunt in composito sicut in subiecto; sed $\mathrm{sunt}$ ab a nima sicut a principio" (Quaest. disp. De anima, a. 19. Podkreślenia moje). 
żności (potentia vitam habens) ${ }^{8}$, tzn. jako ciało zdolne do przejawów życia $z$ racji swej organizacji, a więc zdolne również - w następstwie odpowiednich koordynacji mózgowych - do warunkowania procesów myślenia 9. Dusza ludzka jest pierwszym ,aktem"w przeciwieństwie do ,aktu” w tó r ne g o, którym jest jakakolwiek przez nią ostatecznie urzeczywistniana czynność witalna ${ }^{10}$.

O duszy ludzkiej mówi się z tej racji, że jest we wskazanym sensie pierwszym ,aktem" naszego ciała, ponieważ w tym, co w niej mieści się podstawowego, jest formą substancjalną w stosunku do tego, co w naszym ciele składa się na is totow ą potencjalność, czyli na materię pierws $z a^{11}$, stanowiącą materię fizyczną w jej granicznym, całkowicie jeszcze niezdeterminowanym ujęciu najbardziej fundamentalnym, jakie daje teoria hylemorfizmu w wersji tomistycznej ${ }^{12}$.

Określając duszę ludzką jako formę substancjalną przeczymy, by ona była czynnikiem wytwórczym naszego ciała, istniejacym uprzednio. Przeczymy również, by ona była czynnikiem poruszającym (,motorem”) naszego ciała, wziętego w swym całokształcie lub w jakiejś części - czynnikiem poruszającym, będącym w porównaniu $\mathrm{z}$ tą sferą somatyczną

${ }^{8} \mathrm{Tomasz} z$ Akwinu, Sum, c. Gent., lib. II, cap. LXXI-LXXII; In Aristotelis librum De anima commentarium, lib. II, lect. 1, n. 215, s. 80, n. 222-223, s. $81-82$, n. $229-230$ i 233 , s. 83 , lect. II, n. $240-242$, s. 87 , lect. III, n. 253, s. 91 , lect. IV, n. 275, s. 98; quaest. disp. De anima, a. 2, ad 2; Sum theol., I, qu. LXXV, a. 1, qu. LXXVI, a 4, ad 1, a. 8. ad 2.

We wskazanych tekstach, mających na ogół za przedmiot duszę w ogólności, a nie tylko ludzką, Tomasz wyraża się cizasem w sposób niepełny pisząc, iż dusza jest ,aktem”, ciała (fizycznego i organicznego), nie precyzując bliżej, że jest jego pier w z y m aktem.

9 Jest to komentarz A. D. Sertillanges'a (Le christianisme ei les philosophies, Paris 1946², t. I, 157; L'univers et l'âme, Parig 1965, 64).

10 ,Operationes [...] vitae - pisał Tomasz — comparantur ad animam ut actus secundi ad primum" (Sum. c. Gent., lib. II, cap. LX).

11 Sum. c. Gent., lib. II, cap. LVII (,Quod autem ut propria forma anima corpori uniatur, sic probatur..."), cap. LXVIII-LXIX; In Aristotelis librum De anima commentarium, lib. I, lect. I, n. 221 , s. 81 , n. 223 , s. $81-82$, n. 230 , s. 83 , lect. II, n. 239 , s. 87 , lect. III, n. 253, s. 91 , lect. IV, n. 271, s. 97; quaest. disp. De anima, a. 1; Sum. theol. I, qu. LXXV, a. 5, qu. LXXVI, a. 1.

Gdy przyjmiemy, że dusza jest w nas pierwszą zasada życia, dochodzimy z kolei do przeświadiczenia, że jest ona pierwszym, aktem" i formą substancjalną naszego ciała, podążamy - jak słusznie zauważył Tomasz - drogą poznania aposteriorycznego, gdyż ,ex eo [...] quod anima est forma corporis viventis, est principium operum vitae, et non converso". (Komentarz do De anima, lib. II, lect. III, n. 253, s. 91). Dla uzupelnienia tej uwagi meltodologicznej Tomasza trzeba dodać, iż nie dlatego dusza jest w nas pierwszym, aktem" ciała, że jest pierwszą zasadą właściwego nam życia, lecz dlatego, że jest formą substancjalną.

12 Por.: Remy Collin, Mesure de l’home, Paris 1948, 272, 276. Z ujęciem Collina dobrze harmonizuje określenie zaproponorwane przez Rahnera w Die Hominisation als theologische Frage, w: Paul Overhage und Rahner, Das Problem der Hominisation, Freiburg - Basel - Wien 1961, 51-52: realna negat y w ność (die reale Negativität), która należy do istoty indywidualnego bytu materialnego, stanowiąc jego maksymalne ograniczenia, o jakich można mówić, z , metafizycznego" punktu widzenia. 
czymś realnie odrębnym, przejawiającym siłę $\mathrm{w}$ rozumieniu mechaniki i dokonującym czynności mechanicznych, fizycznych. Dusza ludzka nie pełni ani pierwszej ani drugiej funkcji. Egzemplifikując przynajmniej w pewnym zakresie ten stan rzeczy powiemy za Pawłem $\mathrm{Ch}$ a u char$\mathrm{d}$ e $\mathrm{m}^{13}$, że mózg nie jest maszyną na służbie naszej duszy. Wyrażając się ogólniej zauważymy $\mathrm{z}$ wymienionym autorem ${ }^{14}$, że nie można twierdzić, iż mamy ciało na służbie duszy, jeżelibyśmy przy tej wypowiedzi mieli na myśli dwa byty oddzielone od siebie, $z$ których jeden służy drugiemu. Przyczynowość naszej duszy nie jest w stosunku do ożywianego przez nią ciała przyczynowością sprawczą, która wćnodziłaby w grę w przypadkach, jakie wykluczamy. Ta przyczynowość jest innego rodzaju. Jest to przyczynowość tzw. for malna.

Jej najbardziej istotne przejawy znajdują uwzględnienie $\mathrm{w}$ twierdzeniu, że dusza ludzka jest, jako forma substancjalna, $\mathrm{z}$ a s a dą $\mathrm{kwali-}$ fikacji i organizacji naszego ciała ${ }^{15}$. Jest więc tym, w czym znajduje ostateczne ugruntowanie owa kwalifikacja i organizacja.

Inaczej moglibyśmy wyrazić się, że w człowieku dusza jest, jako forma substancjalna, ideą realną właściwej mu organizacji, jego ,ideą kierowniczą", formułą obiektywną planu dotyczącego rozwoju jego organizmu, krócej - planem idealnym jego konkretnego bytu, planem strukturalnym i funkcjonalnym wpisanym fizycznie $w$ jego ciało, sztuką wewnętrzną jego osobniczego rozwoju, czynnikiem porządkującego w nim wpływu, tym, co stanowi o zawartej w nim ilości informacji, lub jeszcze inaczej - prawem jego konstytucji ludzkiej, prawem właściwym dla jego ciała, prawem istnienia sprawiającym, że jest człowiekiem.

Przytoczone określenia, zapożyczone więcej lub mniej dosłownie od Antonina Sertillangesa ${ }^{16}$ i Michała de Langre'a ${ }^{17}$, należy ro-

13 Notre corps, ce mystère, Paris 1962, 72, 77.

14 Tamże, 105 (wraz z przyp.), 162-163.

15 Wykorzystałem tu formułę Antoniego Stępnia z Wprowadzenia do Metafi$z y k i$, Kraków 1964, 178. Autor ten traktuje duszę ludzka w roli formy substancjalnej jako ,zasadę kwalifikacji i organizacji danego bytu ludzkiego". Podobnych określeń używają w odniesieniu do duszy ludzkiej jako formy substancjalnej względnie w odniesieniu do każdej formy substancjalnej Chauchard (,le principe d'intégration du corps et dans ce corps, le principe intégrateur de structures fluantes" - L'être humain selon Teilhard de Chardin - Ses aspectes complémentaires dans la phénoménologie scientifique et la pensèe chrétienne, Paris 1959,175 i 176 , przyp.) i Michał de Langire (,ce qui confére à chaque être sa structure, ses fonctions, toutes ses propriétés" - Ame humaine et science moderne, Paris 1963, 95; por. s. $96-97,102$ ).

16 La philosophie de saint Thomas, Paris 1940, 84; La philosophie de Claude Bernard, Paris 1944, 100-101; Le christianisme et les philosophies, t. I, 294.

17 Dz. cyt., 89, 91, 94, 97-99, 104, 107-108. - Podobną, jak u Sertillanges'a i de Langre'a, próbę odczytania sensu terminu ,forma substancjalna” znajdujemy w pewnym zakresie u Collina. Autor ten pisał: „on appelle forme l'idée immatérielle ou le plan d'une chose qui tombe sous le sens, donc qui existe actuellement, qui est en acte". (Dz. cyt., 263). 
zumieć $\mathrm{w}$ sensie analogicznym, a nawet częściowo przenośnie. W nich niie chodzi o nic więcej jak o myśl, że w konkretnym bycie ludzkim jest coś, co narzuca naszemu ciału odpowiedni kodeks witalny, jak powiedzielibyśmy za Sertillangesem ${ }^{18}$, mając na uwadze nie poszczególne struktury ciała dostępne poznaniu przyrodniczemu, lecz stojący u ich podstaw ontycznych abstrakcyjnie wyodrębniony $w$ nas czynnik, który sprrawia, że w ogóle żyjemy życiem specyficznie ludzkim.

Przy przedstawionych zastrzeżeniach nie może narzucać się zarzut, że gdy naszą duszę, pojętą jako forma substancjalna, nazywamy tym, co stanowi o zawartej $\mathrm{w}$ nas ilości informacji, schodzimy na tory jakiegoś skrajnego dualizmu, powtarzając w relacji do porządku ontologicznego (w znaczeniu szerszym) to, co przyjmujemy w porządku empiriologicznym, kiedy stosujemy do człowieka teorię informacji. W przytoczonỳm określeniu duszy ludzkiej jako formy sulbstancjalnej chodzi o coś bardziej podstawowego niż to, co uwzględnia cybernetyk, bo o to, co czyni ostatecznie możliwym od strony bytowej stosowanie do człowieka teorii informacji.

Co do prób wyrażenia naszej duszy, jako formy substancjalnej, przy pomocy sformułowań obejmujących terminy: „idea”, „plan”, to tych sfơrmułowań nie należy brać za mieszanie porządku noetycznego $\mathbf{z}$ porządkiem ontycznym. Sformułowania te zostały podjęte $z$ tej racji, że to, co w nich odnosi się do sfery poznawczej, pozwala do pewnego stopnia jako to, co jest dla nas bardziej zrozumiałe - ująć pośrednio, w sposób symboliczny to, co trudniej daje się wyodrębnić bezpośrednio z zakreisu naszej struktury bytowej. Nie zostało więc powiedziane, że nasza dusza, jako forma substancjalna, jest rzeczywiście ideą właściwej nam organizacji, naszą ideą kierowniczą czy planem naszego konkretnego by:tu, lecz że ta dusza przedstawia się z pewnym przybliżeniem we wskazanej roli tak, jakby była tym wszystkim, co zostało wymienione $\mathrm{z}$ porządku poznawczego. Określenia: ,idea r e a ln a ...”, „formuła obiekt"y wna planu...", ,plan strukturalny i funkcjonalny wpisany fizycznie w ciało człowieka", wystarczająco świadczą o afirmowaniu przynależności duszy ludzkiej, rozpatrywanej $\mathrm{w}$ aspekcie formy substancjalnej, do porządlku ontycznego.

3. To, co ze stanowiska tomistycznej filozofii przyrody uderza w duszy ludzkiej we wskazany sposób pojmowanej pod względem jej bytu zàsadniczego i dodatkowego, jest to - jak powiedzielibyśmy, podejmując określenie wysunięte przez Remy Collin ${ }^{19}$ - jej immane n cja w stosunku do naszego ciała. Inaczej moglibyśmy się wyrazić, że jest to ta jej właściwość, iż ożywia nasze ciało „od wewnątrz".

18 La philosophie de saint Thomas, t. II. 1. c.

19 Dz. cyt., $332,339$.

3 - Analecta 
Jest bowiem tak, że w ramach wymienionej dyscypliny uwzględnịa się duszę ludzką o tyle tylko, o ile ona stanowi ontyczny w'spółskładnik naszego ciała, właściwy dlań czynnik konstytuujący, który nie wyróżnia się od jego struktur w płaszczyźnie doświadczenia zewnętrznego (zarówno potocznego, jak i naukowego), dając się jedynie wyodrębnić w drodze abstrakcji, dzięki analizie ontologicznej w znaczeniu szerszym.

Przyjmując na gruncie filozofii przyrody taką sytuację egzystencjalną duszy ludzkiej, przyznaje się w dalszej konsekwencji, że to nie ona jest pełnym i wyłącznym podmiotem czynności fizjologicznych i czynności życia zmysłowego, bo takim pełnym podmiotem jest ciało ludzkie, ukształtowane przez tę duszę jako swą formę substancjalną, albo inaczej - ludzkie compositum w rozumieniu filozofii tomistycznej. $\mathrm{W}$ ten sposób od immanencji duszy ludzkiej, wziętej w relacji do struktury naszego ciała, przechodzi się do jej immanencji ropatrywanej od strony właściwych nam f u n k c j i 20.

Granicznym sformułowaniem myśli o immanencji duszy ludzkkiej jest dla tomistycznej filozofii przyrody bardzo ramowe twierdzenie, domagające się dalszych uściśleń (ale już poza dziedziną wymienionej dyscypliny, bo w sferze metafizyki) - że każdy człowiek stanowi jedną $\mathrm{substancję} \mathrm{żyjącą,} \mathrm{która} \mathrm{jest} \mathrm{równocześnie} \mathrm{substancją} \mathrm{ma}-$ terialną i substancją uzdolniona do przejawów myśli i woli'21. To twierdzenie znajduje - jak można sądzić dobre przygotowanie w ,fenomenologicznej” antropologii Piotra Teilharda de Chardin. Chodzi o sugestie tego autora, że każda jednostka ludzka przedstawia się $\mathrm{z}$ doświadczalnego punktu widzenia jako strumień zjawisk, który stanowi jedną cało ść ${ }^{22}$, że nasza dusza i nasze ciało,

20 Collin mial na uwadzę immanencję duszy ludzkiej wyłącznie w tym drugim znaczeniu. Zoib. dz. cyt., 332 .

21 Jak łatwo zauważyć, pozostaje w trakcie dalszych badań do wyjaśnienia, czy jesteśmy substancją materialną w całokiształcie naszego konkretnego bytu, czy tylko w jego ıczęści, li iczy przejawy myślli i wolli wywoodzą się genetyıznie, jalko ze swego bezpośrediniego podmiotu, $\mathrm{z}$ tego, $100 \mathrm{w}$ mas jest natury materialnej lub może niematerialnej.

Henrylk Bars utrzymuje (L'homme et son âme, Paris 1958, 45), że "quoique j'existe de l'existence de mon âme [...], pourtant mon existence m'est expérimentalement donnée comme physique". To zdanie nie jest wolne od pewnych braków.

Najpierw itrzelba zauważyć, że żadne jednostkowe istnienie, będące tym tylkso, co alktuallizuje talką czy inną isstotę, nie może stanownić z sliebie wystarczającej poodstawy do okkreślenia go jako materialne, fizyczne. Nie ma tistnienia o takich wliaściwościach. Dane istnienie może być jedynie istnieniem bytu materialnego, fizycznego.

A dalej - po wprowadzeniu tej korektury - możemy Barsowi przyznać słuszność a tylle tylko, że $\mathrm{z}$,fenomenollogicznego" punktu widizenia, gdy podiejmujermy penspekty'wę pojęciową właściwą doś́wiadiczeniu zewnętrznemu, nasze istnienie nnajbardziej ,podsitawowe” ukazuje się nam jako istnnienie czegoś materialnego.

22 Les fondements et le fond de l'idée d'évolution, esej z data Wnieborwstapienia r. 1926 - Oeuvres, t. III: La vision du passé, Paris 1957, 186; Le phénomène humain, Oeuvres, t. I, Paris 1955, 57. 
rozpatrywane we wskazany sposób, pojawiają się w tym strumieniu zjawisk jako jego $\mathrm{dwa}$ różne a spekty, dwa różne „oblicza" ${ }^{23}$, dwa zsolidaryzowane ze sobą „ogniska": ognisko organizacji materialnej (un foyer d'organisation matérielle) i ognisko ześrodkowania psychicznego (un foyer de centration psychique) ${ }^{24}$, lub jeszcze inaczej: biegun materialny (un pôle matériel) i biegun „duchowy” (un pôle spirituel) ${ }^{25}$; że nawet duszę ludzką, sprowadzoną do świadomości refleksyjnej, można traktować ze stanowiska doświadczenia naukowego, gdy związki „kazualne" ujmuje się w sposób przyrodniczy - jako specyficzny skutek tej złożoności zorganizowanej, jaką jest nasze ciało ${ }^{26}$. Zmieniając perspektywę pojęciową z ,fenomenologicznej" na ontologiczną w znaczeniu szerszym, możemy na gruncie przytoczonych wypowiedzi Teilharda znaleźć drogę do wysuniętego wyżej twierdzenia granicznego $\mathrm{z}$ dziedziny filozoficznej kosmologii tomistycznej.

4. Aspekt immanencji duszy ludzkiej, który czyni z niej ontologiczny element wszechświata, doskonale uwydatnił ze stanowiska tomistycznej filozofi przyrody Sertillanges. Podkneślił on równocześnie, jak przy uwzględnieniu tego aspektu okazuje się mocną pozycja tomizmu wobec nauk przyrodniczych ${ }^{27}$.

Żywy oddźwięk sformułowań francuskiego dominikanina, niewątpliwie poprawniejszych od 'twierdzeń wysuwanych obecnie przez Karla R ah n e r a ${ }^{28}$, znajdujemy u takich autorów nowszych lub współczesnych, jak Collin ${ }^{29}$, Henryk Bars ${ }^{30}$, de Langre ${ }^{31}$, a zwłaszcza Chauchard ${ }^{32}$.

${ }^{23}$ Le phénomène humain, $l$. c.

24 Dz. cyt., 1. c., pr'zyp. Por. podolbną wypowiedź w Les singularités de l'espèce humaine, „Annales de Paléontologie", t. 41, 1955, Oeuvres, t. II: L'apparition de l'homme, Paris 1956, $334-335$.

25 Les fondements et le fond de l'idée d'évolution, jak wyż., 186.

20 Le phénoméne humain, 334-335, 343; La place de l'homme dans la nature (Le groupe zoologique humain), Oeuvres, t. VIII, Paris 1956, 92; Les singularités de l'espèce humaine, jak wyż., 302.

27 Le christianisme et les philosophies, t. I, 288-297.

28 Die Hominisation als theologische Frage, 49-55; Die Einheit von Geist und Materie im christlichen Glaubensverständnis, w: Schriften zur Theologie, VI, Einsiedieln-Zürich-Köln 1966, 185-214.

Wyporwiedzi Rahnera są skażone przez buddzącą sprzeciw spirytua lizu jąc ą interpretację materii. Jesit to interpnetacja, która wywodzi się z próby spojirzenia na całą materię poprzez czlowieka i z częściowego mieszania analizy ontolologicznej w maczeniu szerszym z analizą empiriologiczną.

29 Dz. cyt., $319-335$.

$30 \mathrm{Dz}$. cyt., $38-43,105$.

31 Dz. cyt., 87-88, 107.

32 Zob. Chaucharda: La foi du savant chrétien, Paris 1957, 50-51, 55-57, 59, 65-66; Biologie et morale, Tours 1959, 22-23, 67, 74: L'être humain selon Teilhard de Chardin ..., $71-72,167-168,171-175,178$; Le système nerveux et ses inconnues, Paris 1959, 124-125; Le cerveau et la conscience, [bmw] 1960, 167-169; Notre corps, ce mystère, 11-18, 30, 51, 63-64, 73, 81, 87-88, 101-102, 105-107, 117, $133,169$. 
Ten ostatni nawiązuje równocześnie w swych wywodach do empirycznej fenomenologii „naukowej”, wziętej głównie w ujęciu Teilharda. Sformułowania paryskiego neurofizjologa filozofującego zasługują na bliższą uwagę $\mathrm{z}$ racji ich trafności.

Może najgłębiej wyraził Chauchard immanencję duszy ludzkiej, gdy napisał, że to, co należy do istoty ciała, co sprawia, że ono jest ciałem specyficznie ludzkim, jest to duch ${ }^{33}$ pełniący funkcję formy substancjalnej ${ }^{34}$. W tym ujęciu rzeczywistość naszego ciała nie ma charakteru czysto materialnego. Jest bowiem tak, że ludzkie ciało czysto materialne nie może istnieć, gdyż $\mathrm{z}$ siebie materia ${ }^{35}$ jest niczym, będąc jedynie możnością bycia wszystkim - a jeżeli istnieje, to $\mathrm{w}$ połączeniu $\mathrm{z}$ formą substancjalną, która sprawia, że jest tym lub owym. W przedstawionej sytuacji ontycznej rzeczywistość ciała ludzkiego odznacza się także charakterem duchowym z racji posiadania dzięki duszy właściwej sobie organizacji ${ }^{36}$.

\section{DUSZA LUDZKA W PERSPEKTYWACH METAFIZYKI}

1. Czy dusza ludzka jest całkowicie i bez reszty immanentną w relacji do ożywianego przez nią ciała tego nie rozstrzyga się $w$ ramach tomistycznej filozofii przyrody.

Dyscyplina ta nie dysponuje zasadami, które umożliwiałyby rozwiązanie zagadnienia, czy nasza dusza jest lub nie jest immanentną pod względem takich czynności, jak czynności intelektualne i wolitywne. Ze strony tomistycznej filozofii przyrody stwierdza się jakościową odrębność przedmiotów tych czynności w porównaniu z przedmiotami zmysłów to że człowiek może np. poznać stosunki rzeczowe odznaczające się abstrakkcyjnością i ogólnością, a przedmiotem formalnym jego woli jest dobro $\mathrm{w}$ ogólności ${ }^{37}$ - ale $\mathrm{z}$ samego tego stwierdzenia nie można jeszcze wyprowadzić żadnego wniosku (niezależnie od tego, jakiego rodzaju rozu-

${ }^{33}$ Znaczenie tego terminu zostanie podane w drugiej części niniejszego artykułu.

${ }_{34}$ Notre corps, ce mystère, 64, 117, 158, 161-162.

35 Chodzi tu o materię pierwszą tomistycznej wersji teorii hylemorfizmu - tę materię, która dla filozofa nawiązującego do Akwinaty jest jedyną materią ściśle rozumianą.

${ }_{36} \mathrm{Dz}$. cyt., 12, 14, 64, 117, 179-180.

37 Uzdolniemie człowieka do poznania stosunków rzeczorwych o charakterze abstrakcyjnym i ogólnym zostanie przedstawione w innej pracy. Ponieważ w niniejszym studium nie będę analizowal przedmiotu formalnego naszej woli, dlatego chiciałbym zaznaczyć przynajmniej tyle, że nawet wtedy, gdy zwracamy się do dólbr poszczególnych, mie zacieśniamy nigdy bez reszty dynamizmu naszej woll do takiej czy innej ich jednostkowej postaci, lecz zawsze wykraczamy jakoś w naszym rozumnym dążeniu poza te dobra w następstwie tego, że - jako istoty uzdolnione do absstrakicji uogólniającej - ujmujemy je pod tym kątem widzenia, że są jakąś częściową i ograniczoną nealizacją dobra w ogólności. 
mowania stanowiłby szczególny przypadek) odnośnie natury bytowej owych czynności, choć daje się dowieść, że wskazaną naturę można jedynie ustalić przez rozpatrywanie istotnych właściwości przedmiotów naszych wyższych czynności psychicznych. W następstwie tego stanu rzeczy nie potrafimy również rozstrzygnąc na gruncie tomistycznej filozofii przyrody, czy dusza ludzka jest lub nie jest wewnętrznie niezależną w swym istnieniu od aktualizowanej przez siebie materii pierwszej.

Tak więc, stwierdzając w obrębie wymienionej nauki filozoficznej aspekt immanencji duszy ludzkiej, pozostawiamy równocześnie otwartą kwestię, czy odkryta immanencja ma charakter w z g lędny l u b b e zwzględny. Dopiero ze strony tomistycznej metafizyki do której, jak sądzę, należy studium ludzkiej duszy in t e lek t u a l n e j, rozpatrywanej w jej bytowej istocie czy naturze - dowodzi się, że ta dusza jest immanentną pod pewnymi jedynie względami, bo

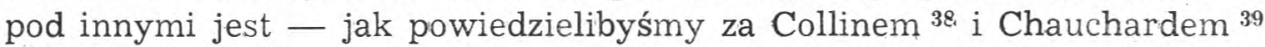
- transcendentną.

Według pierwszego spośród wymienionych tu autorów ${ }^{40}$ można transcendencję ujmować w odniesieniu do przyrody ożywionej na dwa różne sposoby, mianowicie $w$ sensie słabym lub mocnym. Transcendencja $w$ sensie słabym - to transcendencja w rozumieniu czysto o p isowym i ,pozyty w nym”, czyli przyrodniczym, którą uwzględnia się wówczas, gdy stwierdzamy, że ewoluujący kosmos podąża bez przerywania ciągłości zjawisk - od niższych do wyższych, jakościowo odrębnych postaci życia. Transcendencja w sensie mocnym zachodzi znów wtedy, gdy coś, mimo swych zjawiskowych powiązań ze światem fizycznym, wykazuje w stosunku do niego bytow ą niejednorodność i zasadniczą niesprowadzalność.

W ramach tomistycznej metafizyki ujmuje się częściową transcendencję duszy ludzkiej w tym drugim znaczeniu, w znaczeniu mocnym, gdyż ono, a nie znaczenie słabe, posiada charakter metafizyczny. Zamiast mówić o częściowej transcendencji duszy ludzkiej w znaczeniu mocnym, moglibyśmy także wyrazić się, że - według Tomasza z Akwinu - przysługuje jej pod pewnym względem charakter a k o s m i c z n y.

2. O metafizycznie rozumianej, względnej transcendencji duszy ludzkiej czy o jej częściowych właściwościach akosmicznych mówi się tradycyjnie z racji jej duchowości, tzn. z tego powodu, że $1^{\circ}$ niektóre jej czynności, jak akty myślenia i chcenia rozumnego, są czynnościami n i e or g a n i c z n y m i, czynnościami, w których złączona z nią

38 Dz. cyt., 332, 335-347.

39 Notre corps, ce mystère, 54, 58, 73, 133, 140.

$40 \mathrm{Dz}$. cyt., $130-132$. 
materia pierwsza nie uczestniczy $z$ tytułu współpodmiotu ${ }^{41}$ (p e w n a autonomia w płaszczyźnie działania), i $2^{\circ}$ że, istniejąc przez swą własną naturę, przez swe zasadnicze właściwości, jest w swym istnieniu wewnętrznie niezależną od materij pierwszej, aktualizowanej przez siebie ${ }^{42}$ w ludzkim compositum $^{43}$ (pewna autonomia pod względem istnienia) ${ }^{44}$.

41 Zolb. Tomasza: Sum. c. Gent., lib. II, cap. LX, LXII, LXVIII-LXIX, LXXIII; komentarz do De anima, lib. I, lect. XIV, n. 200, s. 73, n. 207, s. 74, lib. II, lect. V, n. 294 , s. 103 , lect. XII, n. 377 , s. 132, lib III, lect. VII, n. 687-688, s. 229 , n. 699 , s. 230 ; quaest. disp. De anima, a. 14; Sum. theol. I, qu. LXXV, a. 2, qu. LXXVI, a. 1, qu. LXXVIII, a. 1, qu. LXXXV, a. 1.

42 Przy tym aktualizowaniu chodzi - jak pisze Stefan Swi e ż a w ski w studium Centralne zagadnienie tomistycznej nauki o duszy (Commensuratio animae ad hoc corpus), „Przegląd Filozoficzny”, 44 (1948) 174 - „o akt odpowiednio dostosowany".

4s Zolb. Tomasza: Sum. c. Gent., lib. II cap. LXXIX-LXXXI; quaest. disp. De anima, a. $1-2,14 ;$ Sum. theol., I, qu. LXXV, a. 6.

44 Wyrażenie o pewnej autonomii w zaknesie działania i istnienia przejąłem od de Langre'a (dz. cyt., 105-106).

Tranıscendencja, jaką $\mathrm{z}$ pozycji metafizyki przypisuje się tradycyjnie duszy ludzkiej, zaczyna się obecnie u niektórych tomistów zacierać w pewnej mierze. Nieraz dzieje się to tylko w sposób pośredni, z tytułu obiektywnych implikacji pewnych sformułowań ogólniejszych.

Mam tu na uwadze więcej lub mniej empiriologiczne podichodzenie do aspektu duchowości naszej duszy względnie lansowanie zbyt szerokiego rozumienia filozoficznego „niematerialności”, wysuwanego w twierdzeniu, że ,nliematerialną" stroną bytu jest istnienie jako takie. Pozwolę sobie przytoczyć in extenso wypowiedź uzewnętrznliającą drugą dążność:

„Jaik niejednolite 'w historii filozofiii było pojęcie materii, tak też niejednolite być musi pojęcie nlematerialności, jako - w stosunku do »materialności« - pojęcie negatywne. U Arystotelesa "niematerialne" było wszystko to, co "oddalało" się do potencjalności, a więc to, co było aktem. I im »wyższy" był bytowy akt, tym bardziej był on niematerialny. Bytowym akitem (substancjalnym) wg Stagiryty jest forma. Wszystkie jednak formy są związane $\mathrm{z}$ elementem potencjalnym, oprócz formy jednej, całkowicie niezwiązanej z materią, formy czystej, arystotelesowskiego Boga. On jeden w systemie Arystotelesa, jako forma czysta, byt niematerialny, bo mbył" miepotencjalny.

„Jeślibyśmy przyjęli intuicje Stagiryty za słuszne w sensie ogólnym, to wg terminologii Tomasza z Akwinu stroną "niematerialną" bytu jest istnienie. I jeśli istnienie to jest istnieniem substancji miezłożonej $\mathrm{w}$ porządku substancji, możemy wówczas mówić o isitotowej niematerialności bytu. Niematerialność absolutna może być tylko tam, gdzie jest Istnienie Czyste, jako Akt Czysty" (Mieczysław A. Krąpiec, Z filozoficznej problematyki badań nad koncepcja materii jako składnika realnego bytu, „Studia Phillosophiae Christianae”, 3 (1967, nr 2) 48, przyp. 58.)

Pomijając kwestie natury historycznej oraz to, co nie należy do poruszanego aktualnie zagadnienia, możemy w oldniesileniu do drugiej części przytoczonego fragmentu pytać się, dlaczego istnlienie wzięte $w$ solbie traktuje się jako miematerialne, skoro jest chyba dostatecznie oczywiste, że ono samo, jako to, co - jak już zauważyłem - aktualizuje tylko daną istotę, nie daje pod tym względem wystarczającego uzasadnienia. Istnienie będzie istnieniem bytu materialnego lub niematerialnego (duchowego) w zależności od tego, jaka jest istota czy natura tego bytu. Biorąc istnienie jako takie za niematerialne, przypisuje się aspektowi egzystencjalnemu w ogólności to, co można przypisać niektórym bytom istniejącym. W ten sposób reifikuje się nieświadomie istnienie, a równocześnie nie pozostawia się nic z samej niematerialności, dopatrując się jej $\mathrm{w}$ elemencie wspólnym dla wszystikich bytów realnych. Nie można również wyrażać się tak, że ,,jeśli istnienie [...] jest istnieniem substancji niezłożonej w porządku substancji, możemy wówczas 
Od tego ujęcia duchowości, wyrażonego w relacji do hylemorfistycznej koncepcji człowieka, można łatwo przejść do ujęcia prostszego, które old wymienionej koncepcji abstrahuje. Wystarczy tylko wziąc za podstawę uproszczenia teoretycznego wnioski przedstawionego rozumienia duchowości: $1^{\circ}$ że przejawy intelektualne i wolitywne nie znajdują zapodmiotowania w ludzkim compositum hylemorfistycznie pojmowanym, lecz są czynnościami samej duszy, i $2^{\circ}$ że dusza może istnieć po zniszczeniu ıwego compositum. Gdy teraz pominiemy złożenie hylemorfistyczne człowieka, możemy powiedzieć, wprowadzając jego bardziej konkretystyczną wizję, że dusza ludzka jest duchową $w$ tym sensie, iż $1^{\circ}$ alkty umysłu i woli są jej wyłącznymi czynnościami, a nie czynnościami mózgu, i $2^{\circ}$ że oprócz tego może istnieć po śmierci ciała.

Uproszczone pojęcie duchowości może być bardzo przydatne w próbach zajęcia stanowiska wobec materialistycznej teorii człowieka. Niemniej jednak pozostaniemy $\mathrm{w}$ dalszym ciągu przy rozumieniu duchowości, jakie osiąga się $\mathrm{w}$ oparciu o teorię hylemorfizmu, gdyż względna transcendencja duszy ludzkiej narzuca się nam najwyraźniej i najpełniej wtedy, gdy dochodzimy do odkrycia właściwej nam duchowości w on t y c znej emergencji ponad naszą strukturę hylemorfic z ną, a więc do odkrycia tego, że nasza dusza nie jest formą substancjalną ,zatopioną" w materii pierwszej, to znaczy przez nią całkowicie opanowana (non est forma in materia corporali immersa, vel ab ea totaliter comprehensa) ${ }^{45}$, lub wyrażając się $\mathrm{z}$ pewnym uproszczeniem, ale w sposób bliższy dla mentalności współczesnej — że nasza dusza nie jest tylko planem strukturalnym i funkcjonalnym bez reszty wpisanym fizycznie w ciało ludzkie albo samym prawem jego istnienia ${ }^{46}$.

To, co może przy wstępnym zapoznaniu się budzić pewien opór w stosunku do tego tradycyjnego ujęcia metafizycznego nawet u tych, którzy w zasadzie przyjmują duchowość duszy ludzkiej, jest to twierdzenie, że wymieniona dusza już teraz, gdy idzie o jej czynności nieorganiczne, duchowe, istnieje do pewnego stopnia 'w niezależności od ciała, jest od niego w jakiejś mierze - jak wyraził się Tomasz - oddzi elona (separata ${ }^{47}$. Trzeba jednak podkreślić że, występując z tym zdaniem, które łączy w pewnym zakresie $\mathrm{z}$ duszą ludzką właściwości pozakosmiczne, myśliciel średniowieczny nie omieszkał bezwłocznie zaznaczyć ${ }^{48}$, iż wła-

mówić o istotowej niematerialności bytu", gdyż w tej wyporwiedzi sprowadza się aspekt egzystencjalny do aspektu esencjalnego.

45 Tomasz z Akwinu, Sum. theol., I, qu. LXXVI, a. 1, ad 4. Podobnie w Sum c. Gent., lib., II, cap. LXVIII (przy końcu), w In Aristotelis librum De anima commentarium, lib. III, lect. VII, n. 688, s. 229 i in. 699 , s. 230 , oraz w quaest. disp. De anima, a. 1, ad 5, a. 2.

${ }_{46}$ Tego rodzaju formułami posłużył się de Langre (dz. cyt., 97-98).

47 Zoib.: Sum. theol., I, qu. LXXVI, a. 1, ad 1; koment. do De anima, n. 699; quaest. disp. De anima, a. 2, ad 1.

48 W Sum. theol., I, qu. LXXVI, a. 1, ad 1. 
dza poznania umyshowego jest $\mathrm{w}$ materi i (in materia est) ${ }^{49}$, o ile dusza, w której tkwi, jest formą substancjalną ciała i kresem rozwoju embrionalnego człowieka.

Przedstawiając naukę Tomasza o względnym oddzieleniu duszy ludzkiej od ciała, chciałbym przypomnieć, że Collin, który również utrzymywał o duszy ludzkiej, iż jest pod pewnym względem oddzielona od ożywianego przez nią ciała ${ }^{50}$, posłużył się jeszcze innym określeniem, mniej może rażącym umysł przyrodniczo wykształcony, że wymieniona dusza wykracza do pewnego stopnia poza porzadek b i o log i c z n y (débordant l'ordre biologique) ${ }^{51}$. Chodzi tu o myśl, którą wyraża również Bars ${ }^{52}$, że dusza ludzka nie zużywa się, nie wyczerpuje się w funkcji ożywiania swego ciała, lecz posiada, jako duch, głębię sobie właściwą.

3. To, co ma charakter duchowy w rozpatrywanym przez nas znaczeniu, jest - z ,fenomenologicznego" punktu widzenia - c a łk o w icie nieoglądowe, pozbawione jakości zmysłowych, rozciągłości i lokalizacji w przestrzeni fizycznej, jest - ściśle rzecz biorac - niewymierne w jednostkach fizykalnych i przedstawia się jako coś niepodzielonego i nie dając ego się dzielić — a więc jako coś, co, wzięte w sobie, jest pozaczasowe czy ponadczasowe. W bliższe szczegóły tego stanu rzeczy wejdę przy innej okazji. Obecnie chciałbym tylko zaznaczyć, że brak zjawiskowych właściwości materii, potraktowany autonomicznie, prowadzi jedynie do empiriologicznego pojęcia niematerialności.

To pojęcie pomija porządek ontologiczny, zatrzymując się bez reszty na jego zjawiskowym przedprożu. Swą treścią różni się w sposób zasadniczy od tradycyjnego, metafizycznego pojęcia duchowości. Z tego też powodu nie jest $\mathrm{w}$ stanie go zastąpić. Jak nietrudno zauważyć, próby przetransponowania klasycznego zagadnienia natury duszy ludzkiej na poziom empiriologicznego pojęcia niematerialności nie mogą nas zaprowadzić do żadnych definitywnych rozstrzygnięć, chociaż nie możemy odmówić pewnej heurystycznej wartości wskazanym wyżej stwierdzeniom ,fenomenologicznym”, które podsuwają nam w jakiejśs mierze myśl, że w naszej osobowości empirycznej jest coś, co nie jest ciałem.

49 Tłumaczenie Swieżawskiego (Sw. Tom a z z A kw in u, Traktat o człowieku - Summa Teologiczna, 1, 75-89, opracował St. Swieżawski, Poznań 1956, 95): ,związana jest z materią" osłania wypowiedź Akwinaty, kktóra przypomina pewme sformułowania Teilharda.

50 Dz. cyt., 344.

51 Tamże, 340 .

52 Dz. cyt., 12-13. 
Empiriologiczne pojęcie niematerialności jest w swej bezpośredniej treści neutralne z filozoficznego punktu widzenia. Mówię: w swej bezpośr edniej treści, bo inna rzecz, jak przedstawilby się epistemologiczny wydźwięk wymienionego pojęcia, gdybyśmy zaczęli rozpatrywać jego on tologic zne i mplikac je typu redukcyjnego. Kiedy abstrahujemy od tych implikacji, musimy przyznać, że omawianym pojęciem może także posługiwać się materialista dialektyczny, jeżeli chce być $\mathrm{w}$ pełni wierny faktom $\mathrm{z}$ dziedziny doświadczenia wewnętrznego. Przykładowo przytoczę Włodzimierza I. Len ina ${ }^{53}$ i Władysława $\mathrm{Kr}$ a je w's ki e g o ${ }^{54}$, którzy doszli do przekonania, że - mimo swego stanowiska materialistycznego - mogą napisać, iż myśl nie jest materialna, to znaczy - jak można sądzić na podstawie kontekstu - że nie ujawnia w sobie $\mathrm{zjawiskowych} \mathrm{właściwości} \mathrm{ma-}$ terii. W jakim stosunku pozostaje to twierdzenie z zakresu empirycznej fenomenologii „naukowej” do tezy filozofii marksistowskiej, że myśl stanowi funkcję ${ }^{55}$ wysoko zorganizowanej materii, czy to twierdzenie nie zawiera czegoś więcej niż uznanie zjawiskowej odrębności myśli od procesów fizjologicznych dokonujących się w mózgu - tego nie potrzebuję abecnie badać, gdyż chodzi mi jedynie o zasygnalizowanie jakościowej różnicy, zachodzącej między empiriologicznym pojęciem niematerialności a metafizycznym pojęciem duchowości ${ }^{56}$.

4. Osobnego podkreślenia domaga się okoliczność, że wysunięcie przez metafizykę tomistyczną tezy o czynnościach nieorganicznych człowieka nie łączy się z twierdzeniem o braku wszelkiego udziału mózgu przy ich realizacji.

Oto, co w tym przedmiocie pisal Tomasz z Akwinu: „O pojmowaniu (intelligere) trzeba powiedzieć, że jest własną czynnością duszy, jeżeli bierze się pod uwagę zasadę, z której wypływa [ta] czynność; nie wypływa bowiem $z$ duszy za pośrednictwem organu cielesnego jak widzenie za pośrednictwem oka. Bierze jednak w niej udział ciało ze strony przedmio-

${ }_{53}$ Materializm a empiriokrytycyzm, tłum. z IV wyd. ros., przygotorwanego przez Instytut Marksa-Engelsa-Lenina przy KC WKP (b), t. 14 Dzieł Lenina, Warszawa $1949,279$.

${ }^{54}$ Materia $i$ materializm $w$ świetle fizyki wspótczesnej, „Myśl Współczesna", (1948), nr 6-7 (25-26) 332; id., Materializm dialektyczny w świetle fizyki współczesnej, Warszawa 1949, 11; Ontologia (Gtówne zagadnienia i kierunki filozofii - Wykłady na Uniwersytecie Warszawskim 1957-1958),Warszawa 1962, 137-138, 144.

55 Gdy lidzie o znaczenie, jakie wiąże się z tym wyrazem w przytoczonej tezie materializmu dialektycznego, zob. Krajewsikiego Ontologię, 134.

56 Od tego ostatniego pojęcia różni się także w sposób zasadniczy pojęcie ,duchowości”, z jakim wystappił spośród autorów marksistowskich Sergiusz L. R u bi ns z te j. n. Tien psycholog utrzymywał (Byt $i$ świadomość, przeł. I. Romam, Warszawa 1961, 430), że poznawicze czynności psychiczne człowieka są ,duchowe”, ale twierdził tak $\mathrm{z}$ tej racji, że wymienione czynności ,zawierają w sobie, wchłaniają w siebie określoną treść ideowa", czyli że przysługuje im intencjonalność w klasycznym rozumieniu. 
tu, gdyż wyobrażenia (phantasmata), które są przedmiotami umysłu, nie mogą powstać bez cielesnych organów"57.

Okazuje się, że chociaż według Tomasza żaden organ cielesny nie uczestniczy $w$ akcie pojmowania, chociaż ten akt jest transcendentny w stosunku do wszystkich procesów dokonujących się w mózgu, to jednak wykazuje on ścisłą łą c zność z tymi spośród nich, które warunkują powstawanie wyobrażeń, będących materiałem wyjściowym dla naszego życia myślowego ${ }^{58}$. Przedstawiony stan rzeczy można wyrazić jeszcze mocniej tak, jak to zrobił Chauchard ${ }^{59}$ pisząc, że myśl jest nieoddzielna od funkcjowania mózgu, bez którego nie miałaby przedmiotu, a przy jego braku nie mogłaby znaleźć urzeczywistnienia.

Biorąc naszą myśl łącznie $z$ tym, co należy do jej nieodzownych uwarunkowań materialnych, powiemy, że dla Tomasza - jak to podkreślił Sertillanges ${ }^{60}$ - nawet najwyższe przejawy psychiczne człowieka były kresem działalności mózgowej, były tym, do czego ta działalność w pewnych wypadkaćn ostatecznie prowadzi. Gdybyśmy chcieli to ujęcie o charakterze metafizycznym wyrazić precyzyjniej, powiedzielibyśmy, że - według myśliciela średniowiecznego - wskazane przejawy są w jedności psychofizycznej, jaką stanowimy, kresem (a nie skutkiem w rozumieniu ontologicznym) aktywności mózgu przy wejściu w grę duchowych uzdolnien.

W tych perspektywach nasza myśl przedstawia się nie jako myśl czystego ducha, ale jako myśl ducha w c i el o n e go. Jest to spostrzeżenie Chaucharda, który twierdzi, że wszelka myśl ludzka jest równocześnie duchową i wcieloną (incarnée), dając się studiować bezpośrednio i od wewnątrz przez psychologię i metafizykę, oraz z zewnątrz i pośrednio (w swych mózgowych infrastrukturach biologicznych) przez neurofizjologię ${ }^{61}$. Za podmiot myśli ludzkiej, wziętej nie w jej samej rzeczywisto-

57 Quaest. disp. De anima, a. 1, ad 11. W Sum. c. Gent., lib. II, cap. LX, Tromasz w ten sposób przedsitawił zależność od ciała umysłu tzw. biernego: „Operatio [...] intellectus possibilis indiget corpore; dicit enim Philosophus (de Anima, III, text. comm. 8) quod anima potest agere per seipsam, scilicet intelligere, quando intellectus est factus in actu per speciem a phantasmatibus abstractam, quae non sunt sine corpore. Igitur intellectus possibilis non est omnino a corpore separatus".

58 Por. de Langre'a dz. cyt., 81-82.

59 Dz. cyt., 80.

60 L'univers et l'âme, 42.

61 Dz. cyt., 63-64. P.or. jeszcze s. 77. - Chauchard utrzymuje również (s. 107), że wolność ludzka nie jest wolnością anielską, lecz wolnością w c i el on ą (une liberté incarnée). „Elle se manifeste" - pisze ten autor - comme [...] une possibilité offerte par l'organisme, le corps". A nieco wcześniej Chauchard wyraża się: „S'il est métaphysiquement exact de rattacher le libre-arbitre à la nature de l'âme humaine et d'affirmer que c'est son insuffisance cérébrale qui empêche l'animal d'être libre, c'est cependant une erreur que faire du libre-arbitre une sorte de pouvoir transcendant, animant de l'extérieur la mécanique corporelle siège de déterminismes limitatifs de la liberté." Por. jeszoze w tym samym dziele Chaucharda s. 109. 
ści specyficznej, lecz łącznie $z$ charakterystycznym dla niej uwarunkowaniem somatycznym, 'trzeba, oczywiście, uważać całego człowieka, to compositum psychofizyczne, jakie on stanowi.

5. Nie podejmując na razie kwestii prawdziwości tezy metafizycznej o nieorganicznym charakterze czynności intelektualnych i wolitywnych, cheiałbym zbadać, c zy ta teza, wzięta w swej obiektywnej osnowie, nie jest sprzeczną z tym, co przyrodnik utrzy$\mathrm{muje}$ na podstawie doświadczenia (i tylko na jego podstawie ${ }^{62}$ ) o $\mathrm{za}$ lézności wymienionych czynności od mózgu? Tak postawione zagadnienie nie zostało może sformułowane poprawnie (czy nie przeocza się tu odrębności epistemologicznych i metodologicznych poznania metafizycznego i przyrodniczego?), ale prowizorycznie biorę je za punkt 'wyjścia dalszych wywodów, gdyż w trakcie szczegółowych analiz sytuacja zapewne się wy'jaśni.

Próbę rozwiązania wysuniętego zagadnienia zacznę od rozpatrzenia, czy nie ma sprzecznościmiędzy tezą, która głosi, iż przejawy myślenia i chcenia rozumnego są czynnościami samej duszy, a twierdzeniem metafizyki tomistycznej o ich somatycznym uwarunkowaniu. Zagadnienie to jest stosunkowo proste pod wzgędem metodologicznym, gdyż występuje w ramach tego samego gatunku epistemologicznego. $\mathrm{Na}-$ tomiast wymieniony wpierw problem okazuje się bardziej złożony, gdyż jest problemem, który pojawia się - jak wydaje się w pierwszej chwili - na styku dwu odrębnych gatunków epistemologicznych, mianowicie metafizyki i nauk przyrodniczych. Stąd też problem ten łatwiej zapewne będziemy mogli rozwiązać po uporaniu się $z$ pierwszym zagadnieniem, do którego teraz przystępuję.

Ze strony metafizyki tomistycznej przyjmuje się, że czynności psychiczne przedstawiane jako nieorganiczne są wewnętrznie nieza leżne od organów cielesnych, a zależą od nich tylko zewnętrzni e. Tak bowiem należy zinterpretować to, co wyżej (n. 2 i 4) zostało powiedziane o stosunku wskazanych czynności do mózgu. Czynności te, w któryćn dokonywaniu materia pierwsza nie uczestniczy z tytułu współpodmiotu, nie mogą być czynnościami żadnego organu cielesnego, lecz samej duszy, a to znaczy, że są wewnętrznie niezależne od jakiegokolwiek organu cielesnego. Ponieważ jednak potrzebują funkcjonowania mózgu, by mogły wejść w posiadanie swego przedmiotu, dlatego musimy powiedzieć, że są zewnętrznie zależne od organu czy organów cielesnych. Mówiąc o tego rodzaju zależności, nie wprowadza się w odniesieniu do nieorganicznych czynności psychicznych żadnych stosunków

62 A więc bez schodzenia na tory wywodów filozoficznych. 
przestrzennych. Uwzględnia się nie coś spacjalnie zewnętrznego w porównaniu z nimi, lecz tylko różnego.

$\mathrm{Z}$ przedstawionych wyjaśnien jest chyba dostatecznie widoczne, że gdy $w$ metafizyce tomistycznej wysuwa się zdanie, iż przejawy myślenia i chcenia rozumnego są, jako czynności nieorganiczne, wewnętrznie niezależne od organów cielesnych, a zależą od nich wyłącznie zewnętrznie - nie wpada się w żadną sprzeczność logiczną. Utrzymuje się przecież, że pod innym względem wymienione przejawy psychiczne są wewnętrznie niezależne od organów cielesnych, a pod innym względem zależne.

Jeżeli tak jest, to $\mathrm{w}$ takim razie trzeba powiedzieć na obecnym, wstępnym etapie naszych badań, że nie musi zachodzić sprzeczność między metafizyczną tezą o nieorganicznych czynnościach psychicznych a tym, co przyrodnik głosi na podstawie doświadczenia o zależności myślenia i chcenia rozumnego od mózgu, a raczej jeżeli dla zachowania ciągłości, jednolitości, a tym samym i sensowności myślenia filozoficznego chcemy pozostać $\mathrm{w}$ ramach tego samego gatunku epistemologicznego i metodologicznego - między tym, co składa się na obiektywne implikacje redukcyjne sformułowań z zakresu psychofizjologii. Przyrodnik nie jest w stanie rozstrzygnąc przy swych perspektywach pojęciowych i metodach badan, zacieśnionych do porządku empiriologicznego, jaka jest natura (typ, rodzaj) zależności naszych najwyższych funkcji psychicznych od mózgu. To zagadnienie odnosi się już do porządku ontologicznego ( $w$ znaczeniu szerszym) i z tej racji nie daje się rozwiązać bez świadomego posługiwania się pojęciami i metodami o charakterze metafizycznym. Otóż, gdyby wymieniona zależność okazała się faktycznie w świetle badań metafizycznych zależnością zewnętrzną ( $w$ przyjętym przez nas znaczeniu) - a jest to wypadek, którego z góry wykluczyć nie możemy - nie byłoby, jak wiemy, sprzeczności między metafizyczną tezą o nieorganicznych czynnościach psychicznych a wypowiedzią psychofizjologa, wziętą w jednej $z$ jej możliwych implikacji metafizycznych typu redukcyjnego.

Możemy teraz przyznać, że nasze zagadnienie nie zostało początkowo sformułowane poprawnie. Okazuje się, że nie występuje ono na styku poznania metafizycznego i przyrodniczego, lecz zamyka się całkowicie w ramach pierwszego $z$ tych dwu gatunków epistemologicznych. Musimy jednakże dodać celem bardziej adekwatnej charakterystyki badanego stanu rzeczy, że przy drugim członie dokonywanego przez nas porównania chodzi o ontologiczne implikacje redukcyjne sformułowań przyrodniczych.

Stwierdziwszy, że dają się pomyśleć takie ontologiczne założenia dla 
wypowiedzi psychofizjologa o zależności myślenia i chcenia rozumnego od. mózgu, przy których można podtrzymywać bez sprzeczności metafizyezną tezę o nieorganicznym charakterze wymienionych czynności, do. chodzimy do wniosku, że w poglądach filozofii tomistycznej nie ma jak można przypuszczać - nic takiego, co nie dałoby się zharmonizować z twierdzeniami przyrodniczymi o somatycznym uwarunkowaniu ,fenomenologicznym" wszystkich, nawet naszych najwyższych przejawów psychicznych.

Jeżeli przyrodnik - powiemy - ogranicza się przy przedstawieniu wyników swych doświadczeń kliniczno-anatomicznych do zarejestrowania wskazanego uwarunkowania, którego filozoficzne implikacje z zakresu jego pozazjawiskowej natury pozostawia do odkrycia badaniom metafizycznym, ma prawo powiedzieć, że kora mózgowa i najwyższe ośrodki podkorowe są - w przysługujących im zakresach - narządem ludzkich procesów psychicznych. To jego twierdzenie nie przesądza tego, że zależność niektórych naszych aktów psychicznych od kory mózgowej może okazać się w trakeie analizy metafizycznej zależnością zewnętrzną. Tak jest dlatego, że przyrodnik posługuje się empiriologicznym pojęciem anatomicznego narządu funkcji psychicznych. Jest to pojęcie, które odnosi się do tego, co w świetle badań doświadczalnych składa się w odniesieniu do zjawisk psychicznych na ich czasowo wcześniejsze lub równoczesne uwarunkowania ze strony organizmu ${ }^{63}$. To złożone pojęcie; wyznaczone w swej treści przez czysto empiriologiczne potraktowanie przyczyn i skutków, czyli - wyrażając się z pewnym uproszczeniem - przez dopatrywanie się w nich samych tylko antecedensów i konsekwensów zjawiskowych, o.bejmuje w swych implikacjach redukcyjnych - jak powiedzielibyśmy ze strony metafizyki - nie tylko narząd będący bliższą współzasadą jakiejś czynności psychicznej, ale również urządzenie anatomiczne, stanowiące $\mathrm{w}$ swym funkcjonowaniu conditio sine qua non pojawienia się danego aktu psychicznego wewnętrznie odeń niezależnego ${ }^{64}$. Ponieważ ze współczesnych wypowiedzi o stosunku psychiki do mózgu nie można nigdy calkowicie wyeliminować empiriologicznego pojęcia jej anatomicznego narządu, dlatego nawet wtedy, gdy psycholog nadaje materialistyczny wydźwięk twierdzeniu, że świadomość jest funkcją (czynnością) mózgu, możemy mu przyznać część słuszności, mianowicie w tym, co w jego sformułowaniu jest wyrazem ,fenomenologicznego" punktu widzenia. 87).

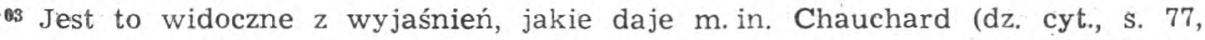
${ }^{64}$ Te dwa wypadki urządzeń anatomicznych nie dają się rozróżnić przy użyciu przyrodniczych metod badań. 
Psychofizjolog może również utrzymywać, że - jak pisze Jan Mazurkiewicz - nie ma czynności czysto psychicznych, gdyż czynności przedstawiane za takie „mają swoje odpowiedniki w swoistych czynnościach korowych" 65. Wszak i tego rodzaju wypowiedź, ukształtowana w perspektywach psychofizycznej jedności człowieka oraz pod kątem widzenia dostępnych dla przyrodniczych metod badań somatycznych uwarunkowań aktów psychicznych, nie wyklucza $z$ siebie tego, że - jak to wyrazi metafizyk - pewne czynności psychiczne, właściwe człowiekowi, zależą od kory wielkich półkul mózgowych ${ }^{66}$ tylko zewnętrznie, bo ich wyłącznym podmiotem jest sama dusza ludzka, a nie dusza i ciało tworzące jedność substancjalną, jak to ma miejsce $\mathrm{w}$ wypadku czynności psychicznych wewnętrznie zależnych od organów cielesnych.

6. Czy to, co narzuca się przyrodnikowi $z$ empiriologicznego punktu widzenia odnośnie somatycznych uzależnień świadomości ludzkiej, zwłaszcza wyższych czynności psychicznych, możemy nazwać materializmem, „na u k ow y m"?

$\mathrm{Za}$ wprowadzeniem takiego określenia opowiedział się — jak wiadomo - Chauchard. W książce La foi du savant chrétien ${ }^{67}$ autor ten odciął się od materializmu „metafizycznego”, natomiast wyraził zdanie, że dogmat katolicki daje się pogodzić w przekonaniach jednej i tej samej jednostki z tym, co jest istotne dla materializmu ,naukowego", czy będzie chodziło o materializm takich racjonalistów jak Jan $\mathrm{R}$ os t a nd, czy o materializm teoretyków marksizmu. Podobne stanowisko, choć wyrażone znacznie ostrożniej, zajął również Chauchard w swej nowszej pracy La pensée scientifique de Teilhard (Paris 1965), w której utrzymuje, że uczeni wierzący jednomyślnie podejmują pozornie materialistyczną koncepcję swoich niewierzących kolegów, zacieśniając ją do ujęcia przyrodniczego i przestając ją brać za wyraz materializmu filozoficznego ${ }^{68}$.

Ustosunkowując się do pierwotnej wersji poglądów Chaucharda trudno nie zauważyć, że ni e ma materializmu ,n a u kow ego", tzn. materializmu wyrażającego się poznaniem czysto przyrodniczym. Materializm pojawia się dopiero $\mathrm{w}$ płaszczyźnie pewnych interpretacji filozoficznych i do tej płaszczyzny noematycznej należy $\mathrm{m}$. in. materializm teoretyków marksizmu. To zaś, co Chauchard nazwał u nich

as Wstęp do psychofizjologii normalnej, t. I: Ewolucja aktywności korowo-psychicznej, Warszawa 1950, 19-20. Por. jeszcze ibid., 87, 144, oraz t. II: Dyssolucja aktywności korowo-psychicznej, Warszawa, 1958, 407,

${ }_{66}$ Nie wchoodzę w 'kwestię, czy nie ma tu jeszcze zalleżności w jakkimś siensie ad trzonu mózgu.

67 S. $9,53-54,58$.

68 S. $199-200$. Por jeszcze s. 201, 206, 213, 217. 
materializmem ,naukowym”, dającym się zharmonizować $z$ dogmatem katolickim, jest to pewien wycinek antropologii fenom enologicznej. Przy obecnym stonowaniu, jakie Chauchard wprowadził do swego ujęcia, zbędność określania: materializm „naukowy” jest zupełnie widoczna, zwłaszcza gdy czytamy w La pensée scientifique de Teilhard ${ }^{69}$, że ów materializm jest to po prostu ,studium naukowe materii" 70.

\section{THE PROBLEM OF THE SOUL IN PHILOSOPHY OF NATURE AND METAPHYSICS}

$\mathrm{S} u \mathrm{~m} m$ a r y

Accordling to the author, an immanence of the human soul, considered in relation soul - boldy, seems to be one the fundamental featuries of the soul examined from the standpoint of Thomistic philosophy of nature. This immanence denotes the propenty of being an inner principle of life and functions for a human body.

In epistemollogical perspectives of the philosophy of mature the problem of the soul can be considered inasmuch as the soul is an ontological co-element of a human body and an appropriate principle of the body constitution. This element canbe distinguilshed, however, on a basils of purely experimental data (either common sense or scientific). It can be examined on the way of abstraction and an ontological analysis only (in the fbroald sense of the last term).

In Thomistic philosophy of nature the soul, because of its specific existentiall situation, cannot be regarded as an complete and exclusive object of sensitive life and physiological functions. Human body for which the soul is an substantial form should be regarded, however, as an similar object. On this way one not can investigate the immanence of the soul not only taking into consideration a structure of a human boldy but also examining slome human functions.

In perspectives of Thomistic phillostophy of mature there is no posisilbillity to answer whether the human soul is completely immanent in relation to a human body animated by it. The mentioned discipline contains no principles enabling to solve the question of immanence in similar acts as acts of intellect and will. The study of the human intellectual soul, its nature, and its ontological essence is possirble in perspectives of Thomistic metaphysics. The problem of relationship between a partial immanence of the soul and its transcendence (ensuing its immateriality) can be defined in this discypline too.

${ }^{69}$ S. 199.

70 Poldoibmie Chauchard wyraził się już w Notre corps, ce mystère (s. 32-33, przyp. 4 , s. $66,72,135,138,140$ ), ale równocześnie posłużył się w tej pracy mało szczęśliiwymi sformułowaniami: ,tłumaczenie materialistyiczne w sensie czysto metodologicznym" (s. 32, przyp. 4), „materializm fenomenologiczny fizjologii nowożytnej" (s. 51) i "materializm funkcjonalny" (s. 71) czy jeszcze "materializm dialektyczny i funiksojonalny" (s. 178). 